\title{
内部酸化した $\mathrm{Cu}-\mathrm{Be}$ 合金の機械的性質についで
}

\section{木 村高 夫** 渡辺康**}

Takao Kimura and Yasushi Watanabe: Mechanical Properties of Internally Oxidized

$\mathrm{Cu}-\mathrm{Be}$ Alloys. The dilute Cu-Be alloys containing Be up to $0.252 \mathrm{wt} \%$ were internally oxidized mainly in the form of a cylinder and partly in the form of a plate to investigate the mechanical properties with respetc to the internal oxidation velocity and dispersed particle size. The results obtained were as follows:

(1) In the cylindrical specmen the internal oxidation velocity is maximum at the external surface and decreases with increasing depth until it increases near the center of the specimen.

(2) As the growth of the dispersed particles is controlled by the internal oxidation velocity, the size of the particles is the smallest at the external surface and increases with increasing depth while it : lecreases near the center of the cylindrical specimen. Therefore the distribution curve of the internal oxidation velocity is in accord with those of the yield strength and the hardness.

(3) The yield behavior of the internally oxidized $\mathrm{Cu}-\mathrm{Be}$ alloys is well explained by the Orowan theory.

(4) The $\mathrm{Cu}-0.047 \mathrm{wt} \%$ Be alloy plate $0.4 \mathrm{~mm}$ in thickness, internally oxidized at $1000^{\circ} \mathrm{C}$ and $50 \%$, cold rolled does not recrystallize even by annealing at $1000^{\circ} \mathrm{C}$ for $6 \mathrm{hrs}$.

(Received August 12, 1965)

\section{I. 緒}

前報(1)においては稀薄な $\mathrm{Cu}-\mathrm{Be}$ 固溶体合金を内部酸化 した際に生ずる組織, 円筒状試料の内部酸化層厚と内部酸 化時間の関保, さらには内部酸化層中の酸素の㹡散につい て検討した結果を報告した。内部酸化した $\mathrm{Cu}$ 合金の機械 的性質については，従来までは Cu 合金粉末から出発して 内部酸化, 压縮, 成形, 押出乙を行なつた試料佂いての 硬度, 引張強さ,クリープ・ラプチャ一強さなどに関する 報告がかなり多いが(2)〜(6)，線材，板材などの比較的大き い試料飞ついては割合少なく(7)〜(10)，乙かも内部酸化によ つて生ずる不均一性比ついては Wood $の \mathrm{Cu}-\mathrm{Al}$ 合金関

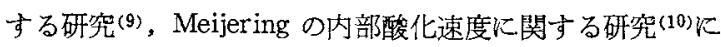
部分的炕しか見当らないようである、それ故、本報では $\mathrm{Cu}$ Be 合金について内部酸化を行なつた際に生ずる機械的性 質の不均一性などを主として検討した結果について報告

** 古河電工中央研究所 (Central Research Laboratory of the Furukawa Electric Co.Ltd., Tokyo)

* 1964 年 4 月本会東京大会で一部発表

(1) 木村, 渡辺: 本誌, 29(1965),885.

(2) W.S. Cremens and N.J. Grant: ASTM Preprint (1958), No.83.

(3) O. Preston and N.J. Grant : Trans, AIME, 221 (1961) ,164.

(4) N.Komatsu, L.J.Bonis and N.J.Grant: Proceedings of the International Conference on Powder Metallurgy, Intersci. Publ.N.Y. (1961), 343.

(5) N. Komatsu and N.J. Grant: Trans. AIME, 224 (1962),705.

(6) M.H.Lew is, R.H. Seebohm and J.W.Martin : Powder Metallurgy, 10(1962),87.

(7) J.W.Martin and G.C.Smith: J.Inst. Metals, 83 (1954 55) , 153 .

(8) M.H.Lewis and J.W.Martin: Acta Met., 11 (1963), 1207 .

(9) D.L.Wood: Trans. AIME, $215(1959), 925$.

(10) J.L.Meijering: ibid, $218(1960), 968$.
する.

\section{II. 実 験 方 法}

試料の準備ならびに内部酸化は前報と同様にして行なつ たのでここでは省略する.今回は試料は主として直径 1.6 $\mathrm{mm}$ の線を使用し，一部 $0.4 \mathrm{~mm}$ 厚の板を使用した.

Table 1 には用いた試料の分析結果を示し，表中に vol \%

Table 1. Chemical analysis of the prepared $\mathrm{Cu}-\mathrm{Be}$ alloys.

\begin{tabular}{c|c|c}
\hline \hline Be content & wt\% & Vol\% \\
Alloy No. & & 0.39 \\
1 B & 0.047 & 0.75 \\
$2 \mathrm{~B}$ & 0.091 & 2.06 \\
3 B & 0.252 & \\
\hline
\end{tabular}

で表わした倡は試料中のBe がすべて内部酸化された場合 の $\mathrm{BeO}$ としての容量百分率を示す．分散粒子間距離の沠 定は内部酸化した円筒状試料を所定の厚さだけ削り扎と し，カーボン 2 段レプリカによる電顕写真をとり前報同様 Fullman(11)の式を用いて行なつた。 また内部酸化した $\mathrm{Cu}$ Be 合金の耐熱性を検討するために，内部酸化した線状試 料では線引きによる加工が不可能であつたので, $0.4 \mathrm{~mm}$ 厚さの試料を $1000^{\circ} \mathrm{C}$ で完全に内部酸化し，冷間圧延を 50 $\%$ 行なつた後，常温より $1000^{\circ} \mathrm{C}$ まの各温度で燒鈍して 降伏強さ，硬度，回折線の積分巾を測定した．積分巾の測 定にあたつては $\mathrm{CuK}_{\alpha}$ による(220)面からの回折線を用い， 二重線の分離は Rachinger の方法(12)によつた。な招引張 試験はすべてテンシロンを使用し，降伏強度は $0.2 \%$ 永久 歪みに括ける強度を採用した。

(11) R.L.Fullman: ibid, $197(1953), 447$.

(12) W.A. Rachinger: J.Sci. Instr., 25 (1948), 254. 


\section{III. 実験結果ならびに考察}

Fig.1 には陚料 $1 \mathrm{~B}, 2 \mathrm{~B}$ を $900^{\circ} \mathrm{C}, 3 \mathrm{~B}$ を $1000^{\circ} \mathrm{C}$ で内部 酸化して，得られた内部酸化層厚と時間の関係を示した。



Fig.1 Penetration depth versus time of internal oxidation in $\mathrm{Cu}-\mathrm{Be}$ wires.

測定点は Meijering の理論式(13)より求めた実線で結んであ るが，前報で報告したごとく実験値とかなりよい一致を示 す. Meijering の式に招いて内部酸化深さを時間で微分す ることにより，円筒状試料断面の各位置に敌ける内部酸化 速度を求めることが出来る. この上うにして求めた円筒状 試料炕括ける内部酸化速度の式を下に示す。

$$
v=-d \rho / d t=\left(C_{1} D_{1} / C_{2}\right) / \rho \ln R / \rho
$$

ここで $v$ : 内部酸化速度, $C_{1}$ ：銅中への酸素の溶解度， $C_{2}$ : 銅中の Be の莀度, $D_{1}$ : 銅中の酸素の桩散恒数, $R$ : 円 筒状試料の半径, $\rho$ : 月筒状試料の中心から内部酸化前線 での距離, $t:$ 内部酸化時間

すなわら，表面における酸素濃度が一定であればすすで 内部酸化した領域に捛ける酸素の拡散恒数が大きい情ど, 溶質原子の濃度の低い汪ぞ内部酸化速度が大きくなる。

Fig.1 のデーターより $C_{1} D_{1}$ の值を求め，(1)式から計算乙 た内部酸化速度を Fig.2 亿示す.内部酸化速度は表面で大 きく内部へ行くにしたがつて減少し，500 $\mu$ 位のところで 最小值を示し，再び中心部で上昇する。このよ5K Meijering の式から内部酸化速度を理論的炕求めることす出来る が，実験的にも測定することが出来る。すなわち Cu-Be 線 状試料を内部酸化中汇温度飞摇動が要ると，組織中に $\mathrm{BeO}$ と考えられる線状の凝集带が現われる(10).この現象は $\mathrm{Cu}$ Be のみ限らず，Cu-Al，Cu-Tìどについても観察され ている(14). Photo.1にはこの現象を利用して試料 3 B 它 $1000^{\circ} \mathrm{C}$ で $20 \mathrm{~min}$ 加熱後 $600^{\circ} \mathrm{C}$ まで急冷し，再び $1000^{\circ} \mathrm{C}$ まで急速加熱し， $1000^{\circ} \mathrm{C}$ で $20 \mathrm{~min}$ 内部酸化を行ない，続 いてまた急冷の操作を繰返すことによつて得た組織を示 す，一定時間に進んだ線間の距離を測定することにより， その層に括ける平均内部酸化速度を求めることが出来る。 この上うにして実験的に求めた平均内部酸化速度は (1) 式

(13) J.L.Meijering and M.J.Druvestyn : Philips Res. Rep., $2(1947), 81$

(14) 木村; 渡辺：未発表
から求めたものとかなりよく一致することが認められた。 つぎに $1 \mathrm{~B}, 2 \mathrm{~B}$ を $900^{\circ} \mathrm{C}, 3 \mathrm{~B}$ を $1000^{\circ} \mathrm{C}$ で完全に内部酸

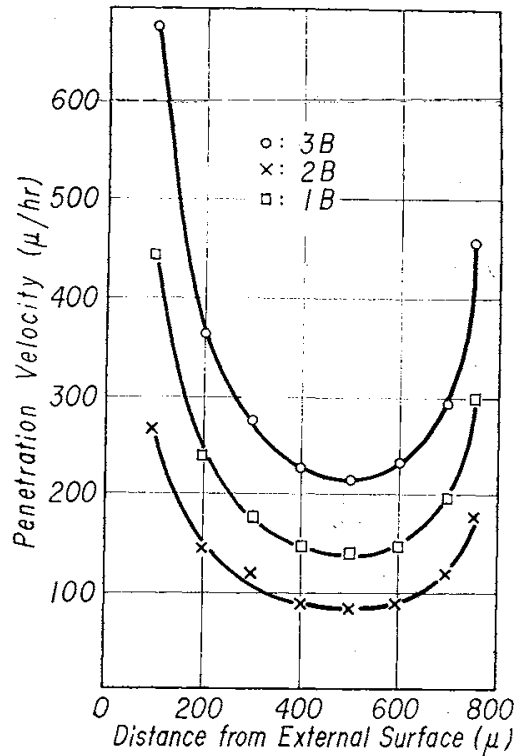

Fig.2 Penetration velocity as a function of distance from surface in internally oxidized $\mathrm{Cu}-\mathrm{Be}$ wires.

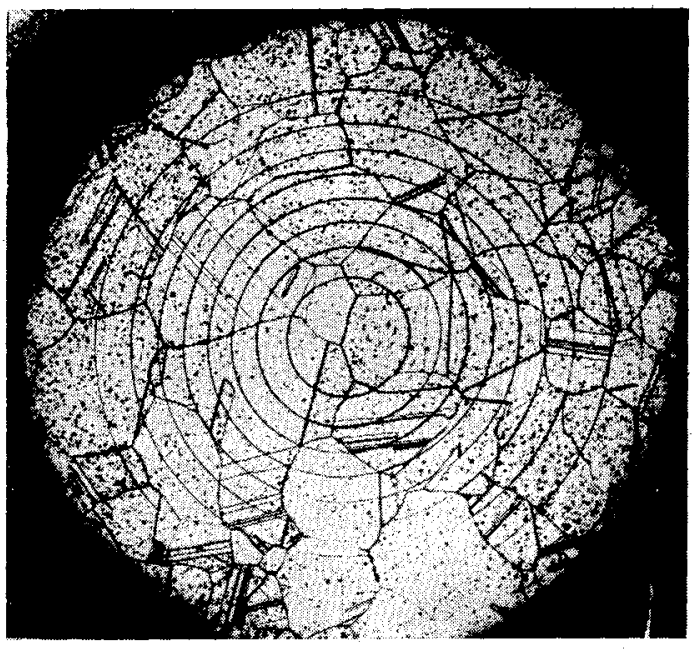

$(\times 50 \times 7 / 8)$

Photo. 1 Concentric rings formed on alternative heating and cooling of $3 \mathrm{~B}$ at $1000^{\circ} \mathrm{C}$.

化したものについて，表面からの距離に対して微小硬度を 湘定した結果をFig.3に示す．溶質元素の濃度に伴な5内 部酸化速度の変化に対して硬度もよく一致しており，いず 机表面で硬度が最も高く内部へ行くにしたがつて減少

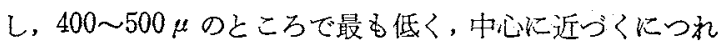
て再び上界し，内部酸化速度の変化と極めてよい対応を示 s.

つぎに Fig.4 亿性試料 $1 \mathrm{~B}$ を $900^{\circ} \mathrm{C}, 3 \mathrm{~B}$ を $1000^{\circ} \mathrm{C}$ で内 部酸化し，内部酸化時間を調整することにより内部酸化層 厚を変元，応力一歪線図を求めた結果を示す。Be 濃度が低 
い1Bでは $\mathrm{BeO} の$ 精界に対する偏析が少ないので伸びが あるが，Be 濃度の高い3Bでは粒界における偏析が大きい

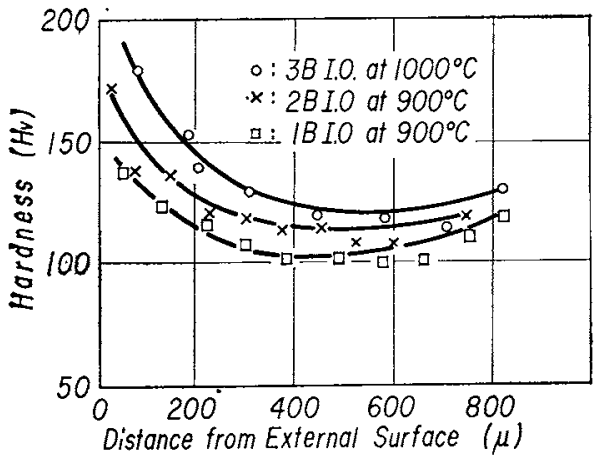

Fig. $3 \mathrm{Hv}$ versus distance from surface in internally oxidized $\mathrm{Cu}-\mathrm{Be}$ wires.

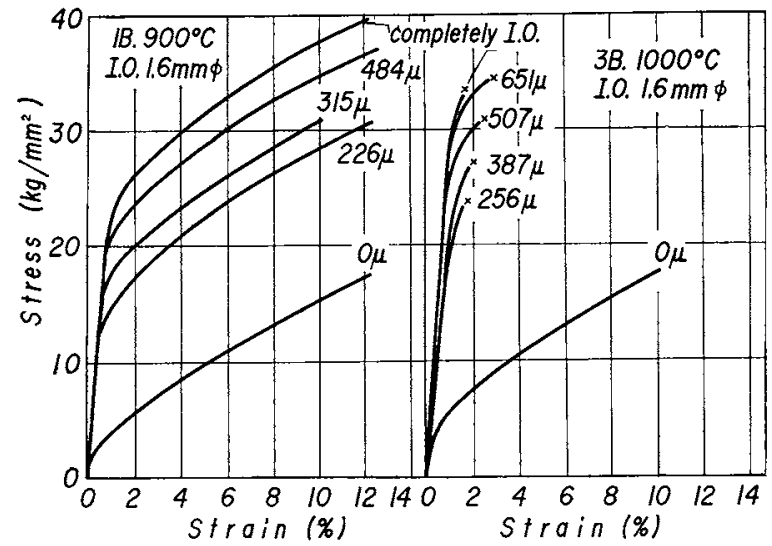

Fig.4 Stress-strain curves of $1 \mathrm{~B}$ internally oxidized at $900^{\circ} \mathrm{C}$ and $3 \mathrm{~B}$ at $1000^{\circ} \mathrm{C}$ with respect to penetration depth.

ために結晶粒界破断を示し，伸びは汪とんどみられない。 内部酸化層がかずが生成することによつて降伏強度が著 しく上年し, 内部酸化層の增加ととむに降伏強度, 初期の 加工硬化速度が增加する.内部酸化した試料では初期にお ける加工硬化は著しいが，引張企の增加とともに加工硬化 が減少し，西る程度以上の歪になると加工硬化速度は内部 酸化していない試料と同程度になる.内部酸化した試料の このような加工硬化挙動は転位の分布ならびに密度によっ て説明することが出来,内部酸化した $\mathrm{Cu}-\mathrm{Al}$ 合金について 報告されている(15)。

つぎに $900^{\circ} \mathrm{C}$ で内部酸化した $1 \mathrm{~B}, 2 \mathrm{~B}, 1000^{\circ} \mathrm{C}$ で内部酸 化した $3 \mathrm{~B}$ 上り内部酸化層厚と降伏強度との関係を求め,

Fig.5 そそと結果を示した。内部酸化された試料では内部 酸化速度, 硬度の結果から予想されるように, 分散粒子が 不均一に存在するために断面の強度は均一ではない。杂 故, 内部酸化されれた線状武料の強度分有を知るために「内 部酸化された線の断面を同心円的に微小区間に分割したと き, 各微小区間に括汁る強度は一定で, 線全体の強度は各 微小区間に括ける強度の和で表わされる」という仮定を行

(15) 木村: Trans. JIM, 6(1965), 217.
ない，以下に示す計算式を導き，各部分の降伏強度を求 めた。

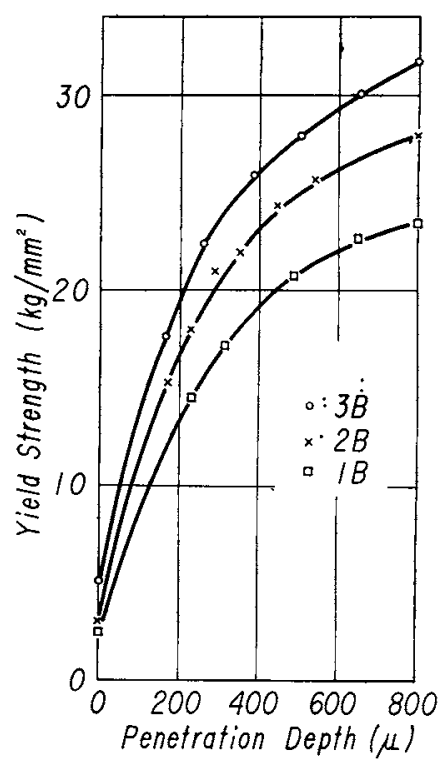

Fig.5 Effect of thickness of internally oxidized layer upon yield strength in $\mathrm{Cu}-\mathrm{Be}$ wires.

$$
x_{n}=S_{n}-S_{n-1}-S_{0}^{(n)}\left\{\left(L_{n} / L_{0}\right)^{2}-\left(L_{n-1} / L_{0}\right)^{2}\right\}
$$

ここで $x_{n}$ : 新しく生じた $\left(L_{n-1}-L_{n}\right) / 2$ なる厚さの内部 酸化層による降伏強度の增加, $S_{n}$ : 内部酸化層の厚さが $\left(L_{0}-L_{n}\right) / 2$ である試料の全体の降伏強度, $S_{n-1}$ : 内部酸 化層の厚さが $\left(L_{0}-L_{n-1}\right) / 2$ である試料の全体の応力-歪 曲線で $S_{n}$ の伸びと等しい伸びに 相当する試料全体の強 度, $S_{0}^{(n)}$ : 内部酸化していない試料の応力-歪曲線で $S_{n}$ の伸びと等しい伸びに相当する試料全体の強度

ただしここでは $S_{n-1}, S_{0}$ をそれぞれの降伏強度で置き換 壳ても誤差虬それはど大きくないので，すべて降伏強度に 置き換えて計算を行なつた，またこの方法で計算するとき には内部酸化によつて生じた分散粒子 $\mathrm{BeO}$ の大きさとそ の分布が内部酸化時間を变光ることによつても変化しない ことが仮定されているが、実際には $\mathrm{BeO}$ の生成エネルギが かなり大さいので， $\mathrm{BeO}$ 粒子の生長は無視出来る。このよ ろにして求めた降伏強度を表面からの距離に対してプロッ トしたのがFig.6である。表面近くで降伏強度は大きく， 内部へ行くにしたがつて減少し， $400 \mu$ の辺りで最小値を 示すが中心の方へ行くにつれて再び上界し，内部酸化速度， 硬度とここでるよい対応を示す。なお中付近に和ける降 伏強度が表面近くのそれよりも高くなつたのは，㦀伏強度 に置き換えて計算したため性じた誤差によるもので ある。

つぎに $1000^{\circ} \mathrm{C} て ゙$ 完全に内部酸化した陚料 $3 \mathrm{~B}$ について， 表面からの距離に対して測定した分散粒子間距離を Fig.7 に示した，粒子間距離は表面近くでは小さく，中心向う につれて増加する，すなわち，表面近くと中心部では内部 酸化速度が大きいために酸素原子と溶質原子とが結合し生 
長する時間が短かく，その結果小さい分散粒子を生じ，粒 子間距離が小さくなるので硬度, 降伏強度が上年する. 試

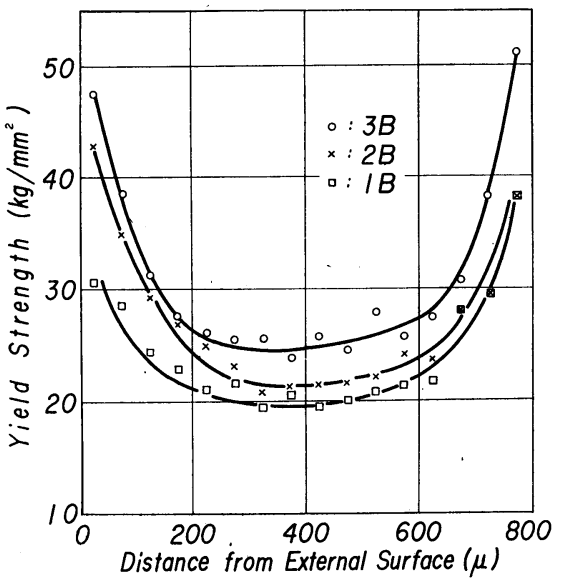

Fig.6 Yield strength as a function of distance from surface in internally oxidized $\mathrm{Cú-Be} \mathrm{wires.}$

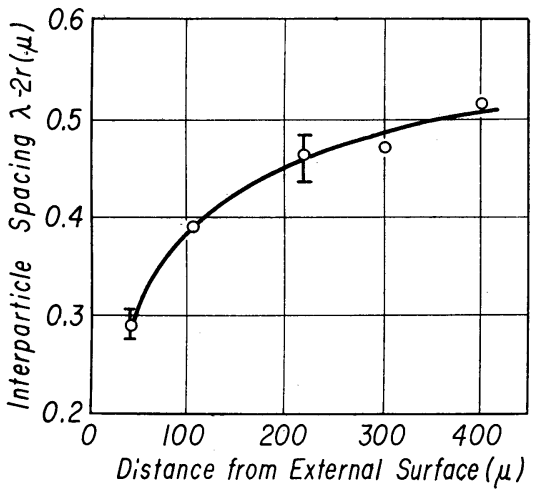

Fig.7 Interparticle spacing versus distance from surface in internally oxidized $3 \mathrm{~B}$ wires.

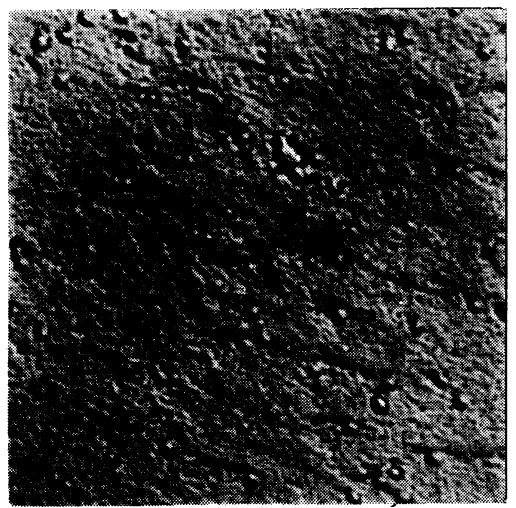

Photo.2 Electron micrograph of internally oxidized $3 \mathrm{~B}$ at the distance of 400 $\mu$ from surface.

料内部へ行くにしたがつて内部酸化速度が小さくなり, 粒 子の生長時間が長くなるので大きい分散粒子を生じ, 粒子 間距離が大きくなるために硬度，降伏強度が減少する。な お Photo.2 には表面より $400 \mu$ における分散粒子の電顕写
真を示した.

分散強化された合金の降伏応力については MottNabarro(16), Orowan(17), Anesll-Lenel(18) の理論があるが, このうち Orowan の理論が最も有力な位置にあり, 分散強 化した $\mathrm{Cu}$ 合 金で成立することが報告されている(8)(19). Orowan にしたがえば分散強化合金の降伏応力と分散粒子 間距離の逆数との間には直線関 係が成立する.ただし， Orowan の理論では分散粒子が存在することによつて生ず

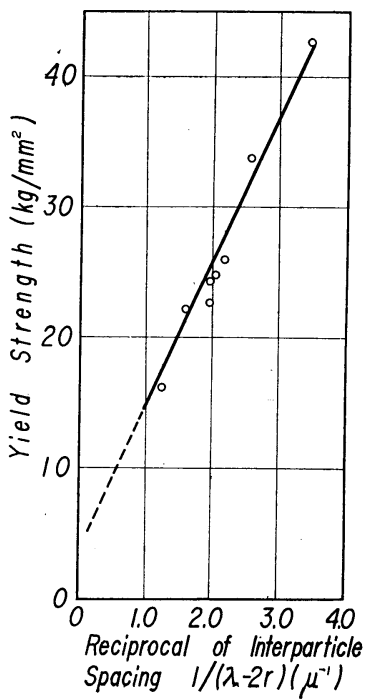

Fig.8 Relationship between yield strength and interparticle spacing in internally oxidized $\mathrm{Cu}-\mathrm{Be}$ alloys.

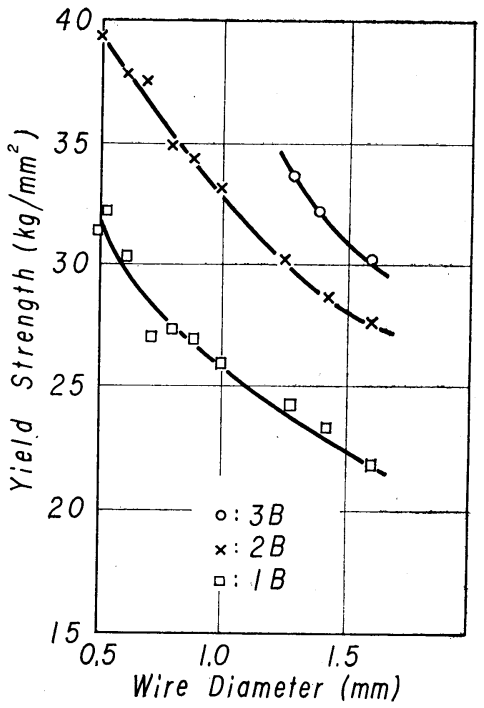

Fig.9 Effect of diameter upon yield strength of internally oxidized $\mathrm{Cu}-\mathrm{Be}$ wires.

(16) N.F.Mott and F.R.N.Nabarro: Proc.Phys. Soc., $52(1940), 86$

(17) E.Orowan: Dislocation in Metals, (1954), 128.

(18) G.S.Ansell and F.V.Lenel: Acta Met., 8(1960), 612.

(19) M.F.Ashby: Z.Metallk., 55(1964),5. 
る応力とか地と粒子の刷性率の差から生じる応力などは無 視されているが，これらの広力は Orowan の式から与えら れる応力 $\left(\approx 10^{-3} \mathrm{G}, \mathrm{G}\right.$ : 翢性率) に比較するとかなり小さい ので( して $1 \mathrm{~B}, 2 \mathrm{~B}$ b部分的に測定し得た粒子間距離の逆数と降

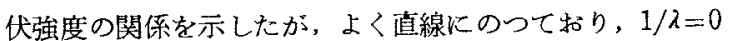
に外挿した值も $3 \mathrm{~kg} / \mathrm{mm}^{2}$ で純銅の降伏強度に一致してい る. 以上のことからら $\mathrm{Cu}-\mathrm{BeO}$ 系でる降伏挙動は Orowanの 考え方で考光てよいことがおかる.

すでに述べたよ5に内部酸化速度によつて分散粒子の大 きさ恱定され，精子間距離によつて降伏挙動が規定され る. それ故, 線径が変化すれば内部酸化速度も変化し, 分



Fig.10 Increase of electric registivity versus diameter in internally oxidized $\mathrm{Cu}-\mathrm{Be}$ wires.

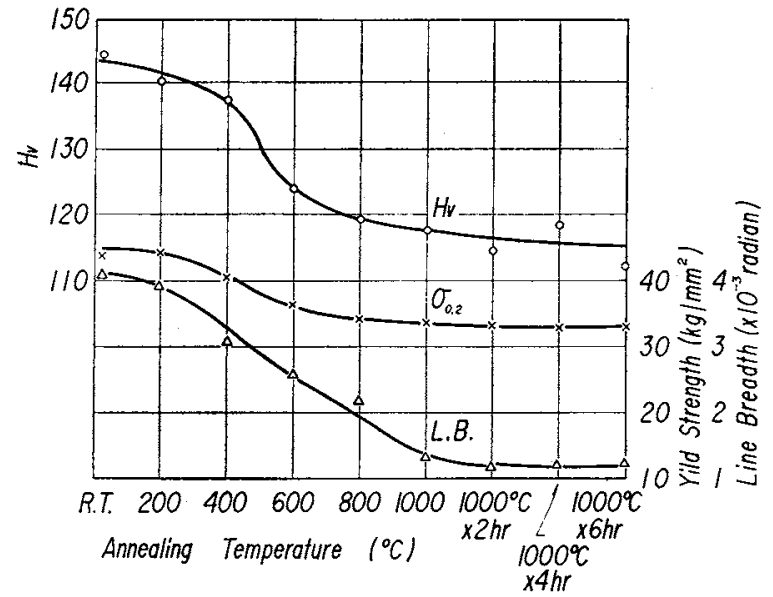

Fig.11 Effect of annealing temperature upon yield strength, Hv and line breadth of internally oxidized and cold rolled $1 \mathrm{~B}$.

散粒子の大きさむ変化するので降伏強度む変化する. 試料 1 B , 2B, 3Bについて線径 $1.6 \mathrm{~mm}$ より $0.5 \mathrm{~mm}$ までのる
のを $1000^{\circ} \mathrm{C}$ で完全に内部酸化し，降伏強度を求め線径と 降伏強度との関係を示したのが Fig.9である.（1) 式から 示されるごとく，線径が小さくなるにつれて内部酸化速度 が著しく上昇し，その結果として精子間距離がかなり減少 するために降伏強度が著しく増加するのであるう。

つぎに. Fig. 10 には $1000^{\circ} \mathrm{C} て ゙$ 完全に内部酸化した試料の 比抵抗の增加と線径の関係を示す，ここで比抵抗の差は純

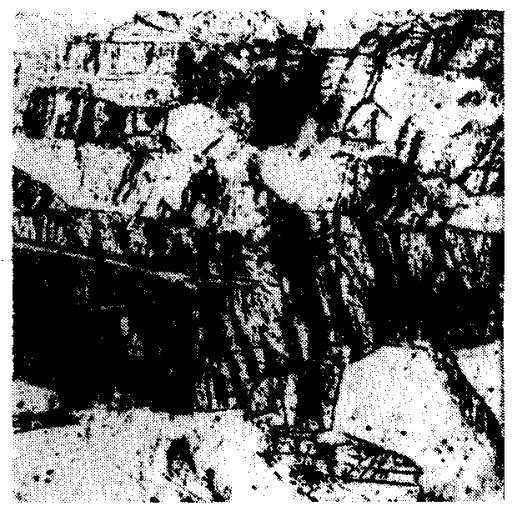

(a)

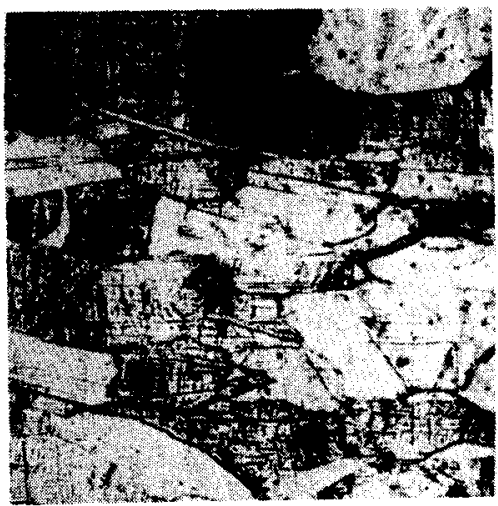

(b)

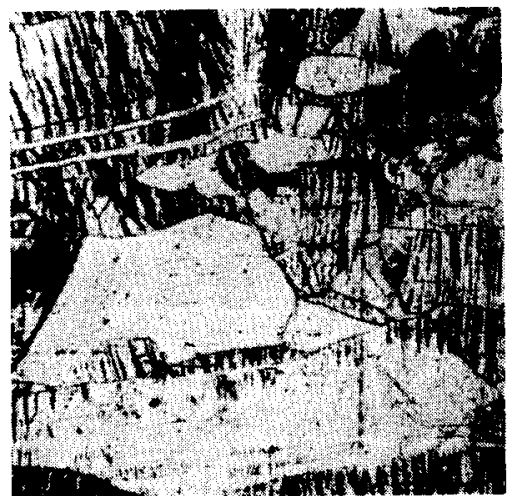

(c)

Photo.3 Microstructures of internally oxidized, cold rolled and annealed $1 \mathrm{~B}$. $(\times 50)$

(a) As cold rolled. (b) Annealed $1 \mathrm{hr}$ at $400^{\circ} \mathrm{C}$. (c) Annealed $1 \mathrm{hr}$ at $800^{\circ} \mathrm{C}$. 
銅との差を示したものであるが，内部酸化した試料の比抵 抗の増加はかなり小さい，比抵抗は線径の減少とともに增



Photo.4 1B internally oxidized and cold rolled.

(a) As cold rolled. (b) Annealed $1 \mathrm{hr}$ at $400^{\circ} \mathrm{C}$. (c) Annealed $1 \mathrm{hr}$ at $800^{\circ} \mathrm{C}$. (d) Annealed $6 \mathrm{hrs}$ at $1000^{\circ} \mathrm{C}$

加するのが認められる．この理由は線径が減少するととも 飞単位体積あたりの分散粒子や粒子の周りの応力場が堌加 するため，電子に対する散乱が大きくなることによるるの であるう。

つぎに. Fig. 11 には厚さ $0.4 \mathrm{~mm}$ 試料 1 B $1000^{\circ} \mathrm{C}$ で 内部酸化後, 約 $50 \%$ 冷間圧延したのについて燃鈍温度に 伴な弓降伏強度, 硬度, 回折線の積分巾の変化を示す. 降 伏強度，硬度，皘分ゆは焼鈍温度の上年とともに同様な举 動をとり，200 $\mathrm{C}$ を過ぎたところで減少しはじめるが $800^{\circ}$ 〜 $1000^{\circ} \mathrm{C}$ の間で注汴一定值となり，その值は内部酸化し たままののよりかなり高い。ついで Photo.3 とは常温， $400^{\circ}, 800^{\circ} \mathrm{C}$ で $1 \mathrm{hr}$ 焼鈍した試料の組織を，Photo.4 Kは 常温, $400^{\circ}, 800^{\circ} \mathrm{C}$ で $1 \mathrm{hr}, 1000^{\circ} \mathrm{C}$ で $6 \mathrm{hr}$ 烧銃した試料 のピンホール写真を示した． $1000^{\circ} \mathrm{C}$ で時間を变えて焼鈍 した試料の組織は $800^{\circ} \mathrm{C} て ゙$ 㜔鈍した組織と全く同様で加
工組織と比較しても变化は認められず，ピンホール写真か らも燒鈍温度の上年とともに $\alpha$ 線の分離が鮮明になるのみ で， $1000^{\circ} \mathrm{C}$ の焼錦では分散粒子存在のために いわゆる再 結晶は生じていない：このことは分散精子の存在によって セルの大きさの小さい安定なセル構造が生ずることによる ものと思われる.同様な現象は内部酸化, 線.引加工した $\mathrm{Cu}-\mathrm{Al}$ 合金 ${ }^{(9)}$, 粉末から内部酸化, 押出しを行なつた $\mathrm{Cu}$ Al 合金など(3)で報告されているが，この状態では正負の 転位の合体に上る消滅々転位の再配列が行なわれ，两る程 度加工歪がとれた回復の段階にあるものと考光られる。

\section{IV. 䋨 論}

$0.047 \sim 0.252 \mathrm{wt} \%$ の $\mathrm{Be}$ を含を $\mathrm{Cu}-\mathrm{Be}$ 合金線を主とし， 一部板について内部酸化を行ない，機械的性質を内部酸化 速度，分散粒子の太きさなどから检討してつぎのような結 果を得た。

（1）円筒状試料では表面で内部酸化速度が最大であり， 内部へ行くにしたがつて減少するが最小值をとつた後，中 心で再び上䒜する.

（2）分散粒子の大ささは内部酸化速度によつて支配さ れ，そのため分散粒子㤬表面で最小であるが，内部へ行く にしたがって大きくなり再び中心部で小さくなる，それ故 内部酸化速度は降伏強度・硬度の分布と一致する。

（3）内部酸化した $\mathrm{Cu}-\mathrm{Be}$ 合金の降伏挙動はOrowan の理 論で説明される。

(4) $0.4 \mathrm{~mm}$ 厚の $\mathrm{Cu}-\mathrm{Be}$ 合金は $1000^{\circ} \mathrm{C}$ で内部酸化して $50 \%$ 冷間圧延を行な つて $1000^{\circ} \mathrm{C} て ゙ 6 \mathrm{hr}$ 焼鈍しても再結晶しない。

終りに臨み，本研究に対して御指導，御助言を賜わつた 東京大学教授橋口隆吉博士ならびに東北大学教授幸田成康 博士に深甚の謝意を表する。 